\title{
PAUXILLITES THADDEI A NEW LOWER ORDOVICIAN HYOLITH FROM MOROCCO
}

\author{
MARTIN VALENT \\ National Museum, Department of Palaeontology, Václavské nám. 68, 11579 Praha 1, the Czech Republic; \\ e-mail: martin_valent@nm.cz \\ JOAN CORBACHO \\ Museo Geológico del Seminario, Diputació 231, 08007 Barcelona, Spain; e-mail: fosilart@hotmail.com
}

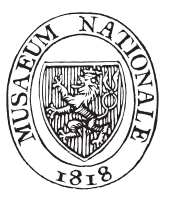

Valent, M., Corbacho, J. (2015): Pauxillites thaddei a new lower Ordovician hyolith from Morocco. - Acta Mus. Nat. Prague, Ser. B, Hist. Nat., 71(1-2): 51-54, Praha. ISSN 1804-6479.

Abstract. A new rare hyolith species Pauxillites thaddei sp. nov. is described from the Lower Ordovician (Floian) Fezouata Formation of Morocco. This new species differs from all other species of the genus Pauxillites MAREK, 1966 by its longer narrow clavicles, which extend to $4 / 5$ of the diameter of the operculum. The newly described species adds to the high diversity of Ordovician hyoliths in the West Gondwana realm.

hyoliths, Hyolitha, Pauxillites, Ordovician, Floian, Morocco.

Received May 13, 2015

Issued September, 2015

\section{Introduction}

Ordovician hyoliths are confined to the sediments of Morocco and do not occur elsewhere in Africa (Valent 2010). Generally, the Ordovician hyolith fauna of Morocco is closely related to that of Bohemia in terms of generic diversity (see Marek 1976 and Valent 2010). Ordovician hyoliths from Morocco were comprehensively studied only by Marek (1983), who described several new taxa, including Pauxillites sp. n., and a new subspecies Pauxillites pauxillus meridionalis MAREK, 1983. Some new localities and hyoliths occurring there were described by Valent et al. (2013) from the Zagora region. This study briefly considers also the type locality of Pauxillites thaddei sp. nov. The aim of the present paper is to describe the new hyolithid species Pauxilites thaddei sp. nov. from the Upper Fezouata Formation, Floian, Lower Ordovician.

\section{Geology}

The Upper Fezouata Formation is a geographically extensive, mainly transgressive unit composed of yellowgreen mudstones and siltstones. In the area around Zagora, south-eastern Morocco, this unit reaches its maximum thickness of $700 \mathrm{~m}$, conformably overlies the siltstones of the Lower Fezouata Formation of late Tremadocian age (Early Ordovician) (Nowak et al. 2015) and locally grades into the sandstones of the middle Arenigian/late Floian (Early Ordovician) Zini Formation (Destombes et al. 1985). The age of the Upper Fezouata Formation is constrained between the early to middle Arenig/early to late Floian (Early Ordovician) (Van Roy and Tetlie 2006). The uppermost part of the Upper Fezouata Formation was assigned to the late Floian (time slice 2c), based on the presence of the chitinozoan Eremochitina baculata brevis (Elaouad-Debbaj 1984, Kröger and Lefebvre 2012).

The studied sample was found at an outcrop located northwest of Jbel Bou Dehir, about $25 \mathrm{~km}$ northwest of the town of Zagora (Text-fig. 1). The coordinates of the site are $\mathrm{N} 30^{\circ} 33.505^{\prime}$ and $\mathrm{W} 005^{\circ} 54.316^{\prime}$. Sediments at this locality are composed of micaceous argillites and siltstones.

The diversified hyolith fauna (genera Nephrotheca?, Cavernolites, Gamaites?, Gompholites and Pauxillites) is known from the Upper Fezouta Formation (Marek 1983). In addition to hyoliths, the fossiliferous layers at the outcrop contain a highly diversified trilobite fauna of different genera and species (Agerina sp.; Asaphellus sp.; Bathycheilus sp.; Colpocoryphe sp.; Euloma sp.; Faulonia sp.; Selenopeltis sp.; Ampyx cf. priscus Thoral, 1935; Lehua adserai Vela et Corbacho, 2007; Lehua corbachoi VelA, 2007; Lehua tahirii CORBACHO, 2008; Lehua velai CORBACHO, 2008; Ormathops clariondi DestomBes, 1972). Other fossils present at this locality are gastropods, bivalves, agnostids and conulariids (Corbacho - personal observation).

\section{Material}

Three almost complete ventral sides and one part of the inner side of an operculum were available for this study.

The slab with these four specimens (numbers GMSB 81381-81384) is stored in the Geological Museum of the Seminary, Barcelona (Spain). The counterpart of the slab contains only counterparts of specimens GMSB 81383 and GMSB 81384, and is stored in the National museum, Prague (the Czech Republic) under numbers NM-S4802a and NM-S4802b. 


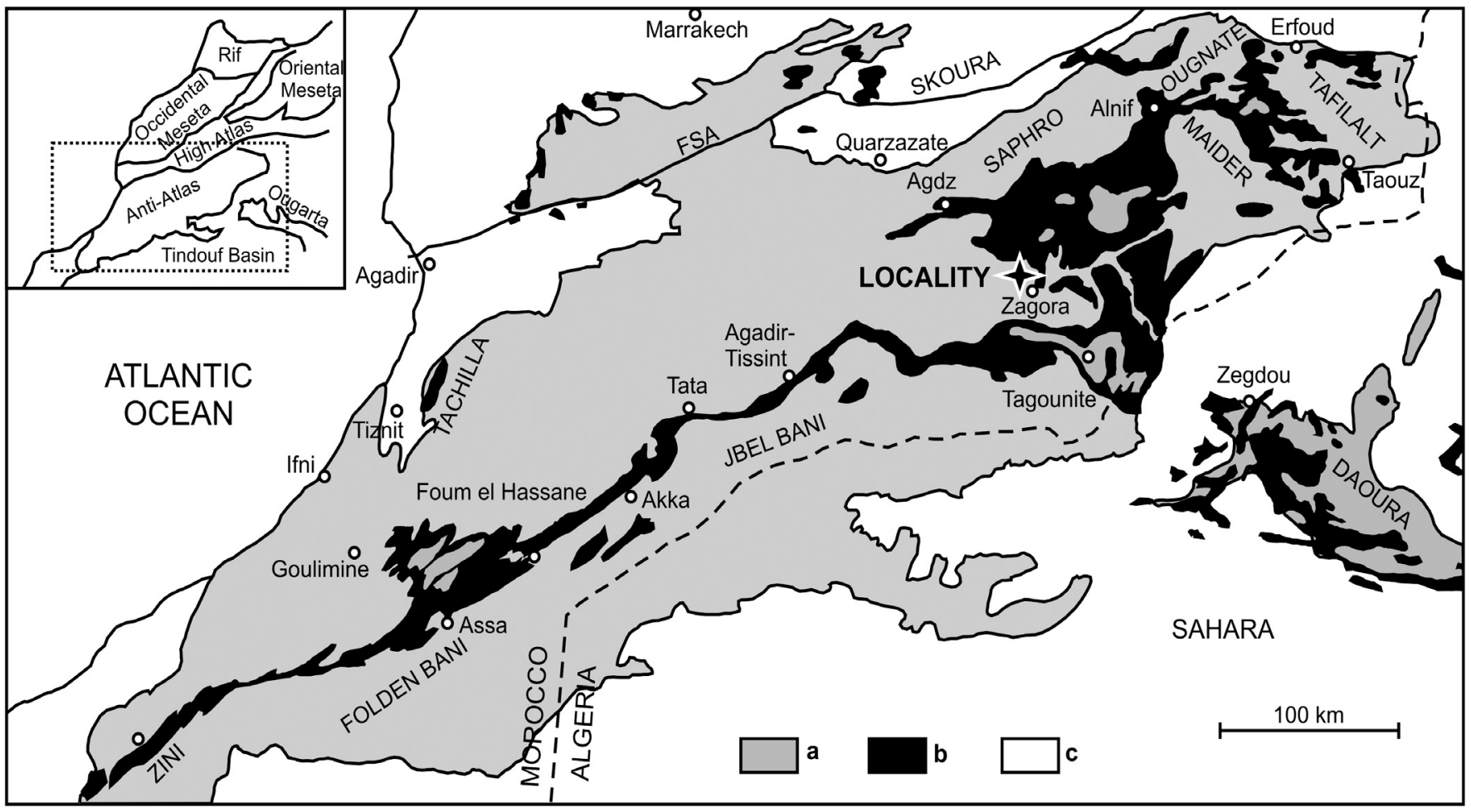

Text-fig. 1. Map of the Anti-Atlas area (Morocco) with the sampled locality in the Zagora region (marked with a black star) (after Gutiérrez-Marco et al. 2003, and Sumrall and Zamora 2011). Key: a, Precambrian and Palaeozoic rocks; b, Ordovician rocks; c, post-Palaeozoic cover.

\section{Systematic palaeontology}

Class: Hyolitha MAREK, 1963

Order: Hyolithida Sysoev, 1957

Family: Pauxillitidae MAREK, 1967

Genus: Pauxillites MAREK, 1966

Type species: Hyolithus pauxillus NovÁk, 1891, Middle Ordovician, Darriwilian, Śárka Formation, Barrandian area, Bohemia, the Czech Republic.

Di i g n o s is. "Shell slightly dorso-ventrally bent; subtrigonal in cross section. Lateral edges sharp. Apertural angle less than $90^{\circ}$, shelf long. Dorsal sculpture consisting of fine longitudinal costae; ventral side marked with growth lines.

Operculum with three pairs of clavicles. Short flattened cardinal processes joined in their basal parts. Cardinal teeth present. One pair of sickle-shaped adductor muscle scars. Surface of operculum with very fine concentric growth lines" (Marek 1966).

Occurrence. Ordovician, Floian - Darriwilian (Arenig - Llanvirn), West Gondwana realm.

S p e c i es. Bohemia: Šárka Formation - Pauxillites pauxillus pauxillus (NovÁK, 1891) and Dobrotivá Formation - Pauxillites latus (ZÁzvorKA, 1928); Morocco: Tachilla Formation - Pauxillites pauxillus meridionalis MAREK, 1983 and Upper Fezouata Formation - Pauxillites sp. n. in Marek (1983) and Pauxillites thaddei sp. nov.

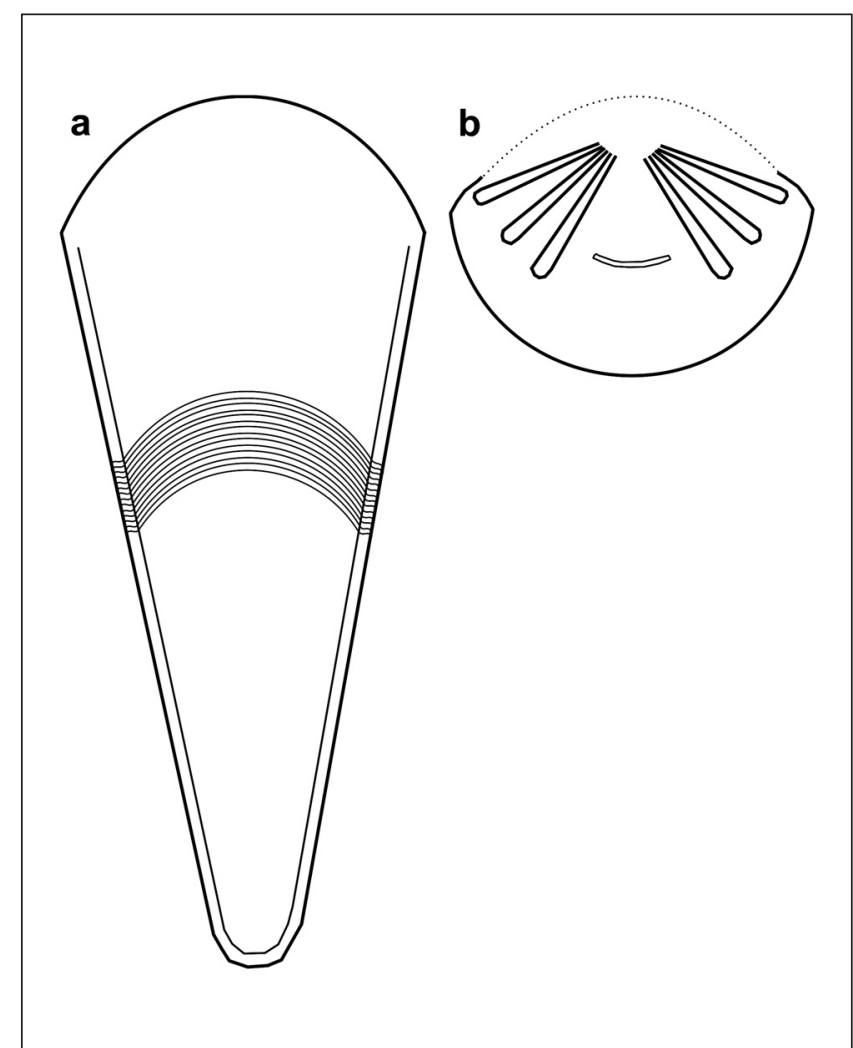

Text-fig. 2. Pauxillites thaddei sp. nov., a - reconstruction of ventral side of conch with visible growth-lines and rounded lateral edges; $b$ - reconstruction of inner surface of triclaviculate operculum with muscle scar in the area between clavicles. The dotted line represents the predicted shape of cardinal area. 

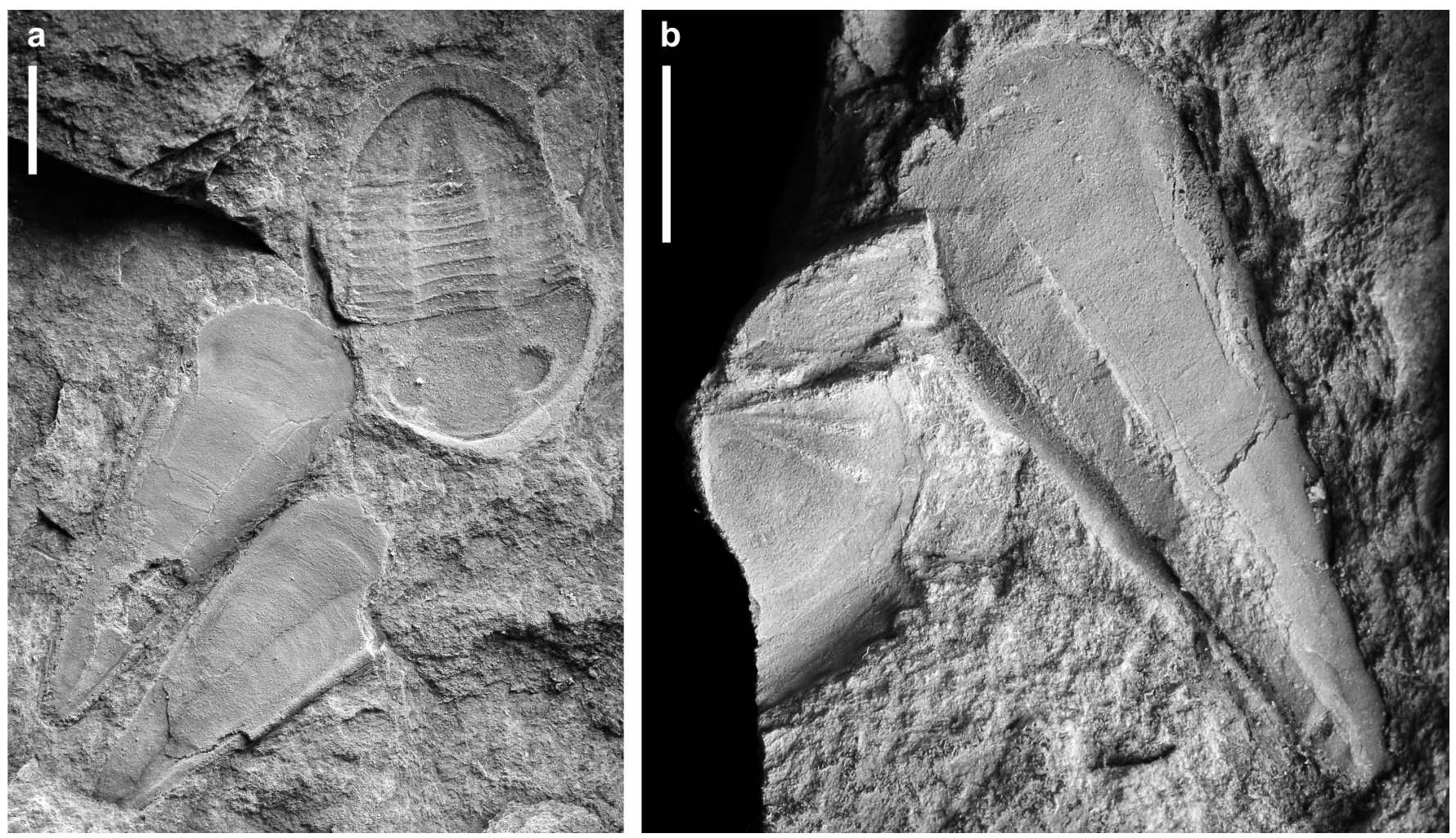

Text-fig. 3. Pauxillites thaddei sp. nov. a - two complete ventral sides (GMSB 81383 and GMSB 81384) with complete trilobite exoskeleton (Asaphellus sp.). b - complete venter (GMSB 81382) together with part of inner surface of triclaviculate operculum (GMSB 81381). Scale bar $5 \mathrm{~mm}$.

\section{Pauxillites thaddei sp. nov.}

Text-fig. 2-3

2013 Pauxillites sp.; Valent et al., 2013, p. 22, fig. 4A.

Hol o ty p e. GMSB 81381 (Text-fig. 3b) part of inner surface of operculum.

Paratypes. GMSB 81382 (Text-fig. 3b), GMSB 81383 and GMSB 81384 (Text-fig. 3a) ventral sides of conch.

Type locality. Outcrop about $25 \mathrm{~km}$ northwest of the town of Zagora, Morocco. The coordinates of the site are $\mathrm{N} 30^{\circ} 33.505^{\prime}$ and $\mathrm{W} 005^{\circ} 54.316^{\prime}$ '.

Type horizon. Upper Fezouata Formation, Floian, Lower Ordovician.

E ty mology. After the Czech name Tadeáś (Thaddeus in Latin).

Material. Rock sample with three ventral sides and one incomplete internal surface of operculum.

D i a g n o s is. Middle-sized hyolithid with strongly rounded ligula, highly rounded dorsum, flat venter and sharply rounded lateral edges. Triclaviculate operculum with long narrow clavicles extending to $4 / 5$ of the operculum diameter.

D e s c r i p ti o n. Middle-sized hyolithid (about $20 \mathrm{~mm}$ long) with straight orthocone conch. Longest specimen $23 \mathrm{~mm}$. Apical angle about $25^{\circ}$. Flat venter with strongly rounded wide ligula. Length of ligula is half of its width. Venter bears fine growth lines. Lateral edges sharply rounded. Based on the operculum, the presumed shape of the complete dorsum was highly rounded. Fragment of dorsum with only fine longitudinal costae; partially visible on the lateral sides of uncovered dorsum. Separate dorsum not found. No other type of ornamentation was ascertained. Type of aperture is not distinguishable.

The size of the triclaviculate operculum clearly corresponds with the nearby ventral side of the conch. The long narrow clavicles are regularly spaced, and reach $4 / 5$ of the operculum diameter. The angle of divergence of the central clavicles is $68^{\circ}$. One elongated bent muscle scar is visible in the area between the clavicles. No muscle scars visible on the conch. No helens were found.

Occurrence. This species is known only from the type locality.

D i s c u s s i o n. The newly described species clearly fits the diagnosis of the genus Pauxillites MAREK, 1966, in the morphology of the conch and triclaviculate operculum. Pauxillites thaddei sp. nov. resembles the subspecies Pauxillites pauxillus meridionalis MAREK, 1983 (Upper Fezouata Formation, Floian, Lower Ordovician; Morocco) in the distribution of clavicles, but differs in having substantially longer clavicles, which extend to $4 / 5$ of the operculum diameter. 


\section{Acknowledgements}

We would like to express our thanks to Oldřich Fatka and Petr Budil for helpful comments and suggestions which greatly improved the clarity of the paper. This work was financially supported by the Ministry of Culture of the Czech Republic (DKRVO 2015/04, National Museum, 00023272).

\section{References}

Destombes, J., Hollard, H., Willefert, S. (1985): Lower Palaeozoic rocks of Morocco. - In: Holland, C. H. (ed.), Lower Palaeozoic Rocks of the World, Volume 4: Lower Palaeozoic of North-western and West-central Africa, John Wiley \& Sons, Chichester, p. 91-336.

Elaouad-Debbaj, Z. (1984): Acritarches et chitinozoaires de l'Arenig-Llanvirn de l'Anti-Atlas (Maroc). - Revue de Paléobotanique et de Palynologie, 43: 67-88. http://dx.doi.org/10.1016/0034-6667(84)90027-7

Gutiérrez-Marco, J. C., Destombes, J., Rábano, I., Aceolaza, G. F., Sermiento, G. N., San José, M. Á. (2003): Ordovician of the Moroccan Anti-Atlas: Paleobiodiversity, biostratigraphic review and correlation. Geobios, 36(2): 151-177. http://dx.doi.org/10.1016/S0016-6995(03)00004-4

Kröger, B., Lefebvre, B. (2012): Palaeogeography and palaeoecology of early Floian (Early Ordovician) cephalopods from the Upper Fezouata Formation, Anti-Atlas, Morocco. - Fossil Record, 15(2): 61-75. http://dx.doi.org/10.5194/fr-15-61-2012

Marek, L. (1963): New knowledge on the morphology of Hyolithes. - Sborník geologických věd, Paleontologie, 1: 53-73.

Marek, L. (1966): New hyolithid genera from the Ordovician of Bohemia. - Časopis Národního muzea, oddíl přírodovědný, 135(2): 89-92.
Marek, L. (1967): The Class Hyolitha in the Caradoc of Bohemia. - Sborník geologických věd, Paleontologie, 9: 51-113.

Marek, L. (1976): The Distribution of the Mediterranean Ordovician Hyolitha. - In: Bassett, M. G. (ed.), The Ordovician System: proceedings of a Palaeontological Association symposium, Birmingham, University of Wales Press and National Museum of Wales, Birmingham, p. 491-499.

Marek, L. (1983): The Ordovician Hyolitha of Anti-Atlas (Morocco). - Sborník Národního muzea v Praze, Řada B, Př́írodní vědy, 39: 1-36.

Nowak, H., Akodad, M., Lefebvre, B., Servais, T. (2015): Discovery of the messaoudensis-trifidum acritarch assemblage (upper Tremadocian-lower Floian, Lower Ordovician) in the subsurface of Morocco. - Estonian Journal of Earth Sciences, 64(1): 80-83. http://dx.doi.org/10.3176/earth.2015.14

Sumrall, C. D., Zamora, S. (2011): Ordovician edrioasteroids from Morocco: faunal exchanges across the Rheic Ocean. - Journal of Systematic Palaeontology, 9(3): 425-454. http://dx.doi.org/10.1080/14772019.2010.499137

Sysoev, A.V. (1957): K morfologii, sistematicheskomu polozheniyu i sistematike chiolotov [On the morphology, systematic position and systematics of hyoliths]. Doklady Akademii Nauk SSSR, 116(2): 304-307. (in Russian)

Valent, M. (2010): Palaeogeographic distribution of Ordovician hyoliths. - Journal of the National Museum (Prague), Natural History Series, 179(17): 179-182.

Valent, M., Corbacho, J., Martínez, D. (2013): Hyolith localities of Zagora region (Morocco), Upper Fezouata Formation (Lower Ordovician). - Batalleria, 19: 20-23.

Van Roy, P., Tetlie, O. E. (2006): A spinose appendage fragment of a problematic arthropod from the Early Ordovician of Morocco. - Acta Palaeontologica Polonica, 51(2): 239-246. 